\title{
PENGARUH PROTEKSI CPO DENGAN FORMALDEHID TERHADAP KECERNAAN DAN PERFORMA DOMBA EKOR TIPIS
}

\section{THE EFFECT OF CPO PROTECTED WITH FORMALDEHYDE ON DIGESTIBILITY AND PERFORMANCE OF THIN TAIL SHEEPS}

\author{
Nafly Comilo Tiven ${ }^{1 *}$, Lies Mira Yusiati ${ }^{2}$, Rusman $^{2}$, dan Umar Santoso ${ }^{3}$ \\ 1Jurusan Peternakan, Fakultas Pertanian, Universitas Pattimura, Ambon, 97233 \\ ${ }^{2}$ Fakultas Peternakan, Universitas Gadjah Mada, Yogyakarta, 55281 \\ ${ }^{3}$ Fakultas Teknologi Pertanian, Universitas Gadjah Mada, Yogyakarta, 55281
}

Submitted: 19 January 2015, Accepted: 3 March 2015

\section{INTISARI}

Penelitian ini dilakukan untuk mengetahui pengaruh proteksi crude palm oil (CPO) dengan formaldehid terhadap kecernaan dan performa domba ekor tipis. Sebanyak 15 ekor domba lokal jantan berumur 9-12 bulan, dibagi menjadi 3 kelompok perlakuan ransum, yaitu kelompok pertama hanya mendapat ransum basal (R0), kelompok kedua mendapat ransum basal dan 3\% CPO (R1), sedangkan kelompok ketiga mendapat ransum basal dan 3\% CPO yang diproteksi dengan $2 \%$ formaldehid (R2). Data dianalisis menggunakan Rancangan Acak Lengkap pola searah. Perbedaan antar perlakuan diuji lanjut dengan Duncan's New Multiple Range Test. Hasil penelitian menunjukkan bahwa proteksi CPO dengan formaldehid (R2) dalam ransum berpengaruh tidak nyata terhadap konsumsi bahan kering, konsumsi bahan organik, kecernaan bahan kering, kecernaan bahan organik, pertambahan berat badan harian $(\mathrm{PBBH})$, tetapi berpengaruh sangat nyata $(\mathrm{P}<0,01)$ meningkatkan angka konversi pakan. Dapat disimpulkan bahwa proteksi CPO dengan formaldehid lebih menguntungkan dari aspek konversi pakan.

(Kata kunci: Domba ekor tipis, Crude palm oil (CPO) terproteksi formaldehid, Kecernaan, Performa)

\section{ABSTRACT}

The experiment was conducted to determine the effect of CPO protected with formaldehyde on digestibility and performance of thin tail sheeps. Fifteen local male lambs aged 9-12 months, were divided into 3 groups of ration treatment. The first group received only the basal ration (RO), the second group received the basal ration and 3\% CPO (R1), while the third group received the basal ration and $3 \%$ CPO protected with $2 \%$ formaldehyde (R2). The data were analyzed by Completely Randomized Design with oneway pattern. The different of treatments were tested by Duncan's New Multiple Range Test. The results showed that addition CPO protected with formaldehid (R2) in the sheeps diet did not affect dry matter and organic matter intake, dry matter and organic matter digestibility, average daily gain (ADG), but significantly $(P<0.01)$ increase feed conversion rate. It can be concluded that CPO protected with formaldehyde gives more advantage on feed conversion aspect.

(Key words: Thin tail sheeps, Crude palm oil (CPO) protected with formaldehyde, Digestibility, Performance)

\section{Pendahuluan}

Lemak sering ditambahkan dalam ransum ternak ruminansia untuk meningkatkan palatabilitas ransum, sebagai sumber energi, serta sebagai sumber asam lemak tidak jenuh esensial. Ransum yang kaya asam lemak tidak jenuh esensial, dapat memperkaya asam lemak tidak jenuh esensial dalam daging (Felton dan Kerley, 2004), yang dapat menurunkan kolesterol

\footnotetext{
${ }^{*}$ Korespondensi (corresponding author):

Telp. +62 81328668298

E-mail: nafly_tiven@yahoo.co.id
}

serta mengurangi resiko penyakit jantung pada konsumen (Willett, 2007; Harris, 2010). Minyak sawit kasar (Crude Palm Oil CPO), merupakan sumber lemak yang dapat digunakan dalam ransum karena mengandung asam lemak tidak jenuh ganda (Polyunsaturated Fatty Acid - PUFA) yang relatif tinggi. Kandungan asam lemak minyak kelapa sawit yang tergolong asam lemak jenuh (Saturated Fatty Acid - SAFA) antara lain asam laurat (C12:0) 0,50\%, miristat (C14:0) 0,92\%, palmitat (C16:0) 36,84\% dan 
stearat (C18:0) 4,77\%, yang tergolong asam lemak tidak jenuh tunggal (Monounsaturated Fatty Acid - MUFA) antara lain asam oleat (C18:1) 44,51\%, sedangkan yang tergolong asam lemak tidak jenuh ganda (Polyunsaturated Fatty Acid - PUFA) antara lain linoleat (C18:2) 11,12\%, linolenat (C18:3) 0,24\% (Sampaio et al., 2011).

Pemberian ransum yang kaya akan kandungan asam lemak tidak jenuh pada ternak ruminansia sangatlah terbatas, yaitu maksimal 5\% dari bahan kering (Doreau dan Chilliard, 1996), karena akan mengganggu fermentasi rumen dan mengurangi pemanfaatan serat (Hristov et al., 2009; Vafa et al., 2009). Drackley (2007) menyatakan bahwa asam lemak tidak jenuh beracun bagi banyak spesies bakteri rumen, terutama yang terlibat dalam pencernaan serat, karena lemak dapat membungkus partikel pakan sehingga menutup akses permukaan membran sel mikrobia bersentuhan dengan pakan yang dapat mengganggu produksi enzim untuk mendegradasi pakan (Johnson, 2007) dan berefek pada penurunan kecernaan pakan.

Salah satu cara untuk mengurangi efek negatif lemak bagi ternak ruminansia adalah dengan memproteksi pakan sumber asam lemak dengan formaldehid, sehingga pakan sumber asam lemak tersebut tidak terdegradasi dalam rumen. Prinsipnya, pakan sumber asam lemak yang diproteksi, yang kaya asam lemak tidak jenuh esensial, akan tahan terhadap suasana $\mathrm{pH}$ 6-7 di retikulo rumen, tetapi akan terlepas pada suasana $\mathrm{pH}$ 2-3 di abomasum dan akhirnya dapat diserap di usus halus (Scott et al., 1970). Penelitian in vitro yang telah dilakukan, diperoleh hasil bahwa CPO sebagai sumber asam lemak sebanyak 3\% dari bahan kering yang diproteksi dengan formaldehid sebanyak $2 \%$, dapat melindungi asam lemak tidak jenuh dari hidrogenasi mikrobia rumen (Tiven et al., 2011a) serta tidak berefek negatif terhadap parameter fermentasi dan aktivitas mikrobia rumen (Tiven et al., 2011b).

Selain dapat memproteksi asam lemak tidak jenuh, penggunaan formaldehid dipilih karena murah dan mudah dibuat serta relatif tidak berbahaya karena dapat dengan cepat didetoksifikasi. Apabila diabsorpsi dalam darah, formaldehid akan dimetabolisme menjadi asam format kemudian akan diekskresikan melalui urin sebagai garam sodium atau dioksidasi lebih lanjut menjadi karbondioksida dan air (Wartew, 1983). Proses detoksifikasi akan berjalan efektif pada konsentrasi formaldehid yang rendah, sebaliknya pada konsentrasi yang tinggi akan menyebabkan asidosis dan kerusakan jaringan, menurunkan kelarutan protein sehingga sulit tercerna dalam usus halus (Sharma dan Gupta, 1984) serta menurunkan kecernaan enzimatis dalam usus (Antoniewicz et al., 1992).

Penelitian ini dilakukan dengan tujuan untuk mengetahui pengaruh proteksi CPO dengan formaldehid terhadap kecernaan dan performa ternak domba. Hasil penelitian ini diharapkan dapat menjadi acuan penggunaan pakan yang tinggi kadar asam lemak tidak jenuhnya serta tidak mempunyai efek negatif terhadap kecernaan pakan.

\section{Materi dan Metode}

\section{Materi}

Ternak. Sebanyak 15 ekor domba ekor tipis jantan berumur 9-12 bulan dengan bobot badan sekitar 14-17 kg dipelihara dalam kandang individual berbentuk panggung yang dilengkapi tempat makan dan minum. Ternak domba dibagi secara acak menjadi 3 kelompok sesuai dengan perlakuan pakan, masing-masing kelompok terdiri dari 5 ekor.

Pakan. Ransum basal yang digunakan terdiri dari hijauan dan konsentrat dengan perbandingan 60:40. Hijauan yang digunakan adalah rumput gajah, sedangkan konsentrat yang digunakan terdiri dari 30\% bekatul dan 10\% bungkil kedelai. Adapun kandungan nutrien ransum basalnya adalah $62,98 \%$ TDN, $45,50 \%$ bahan kering, $14,48 \%$ protein kasar, $4,70 \%$ lemak kasar dan $21,93 \%$ serat kasar. Kelompok ternak pertama hanya mendapat ransum basal (R0), kelompok kedua mendapat ransum basal dan 3\% CPO (\% BK) tanpa diproteksi dengan formaldehid (R1) serta kelompok ketiga mendapat ransum basal, 3\% CPO $(\%$ $\mathrm{BK}$ ) yang diproteksi dengan $2 \%$ formaldehid (R2).

\section{Metode}

Pemeliharaan ternak. Domba dipelihara selama 3 bulan dan diberi ransum sebanyak $4,3 \%$ dari berat badan. Pemberian pakan dilakukan dua kali sehari, yaitu pagi hari pada pukul 08.00 dan sore hari pada 
pukul 15.00 , sedangkan air minum diberikan secara ad libitum. Selama pemeliharaan dicatat jumlah konsumsi harian setiap ternak. Domba ditimbang seminggu sekali untuk mengetahui berat badannya dan untuk menyesuaikan jumlah ransum yang diberikan.

Untuk data kecernaan, koleksi dilakukan selama 1 minggu. Sampel pakan yang diberikan pada ternak, diambil setiap hari sebanyak $100 \mathrm{~g}$ rumput gajah dan $10 \mathrm{~g}$ konsentrat. Sebelum ternak diberi pakan, sisa pakan dan feses masing-masing ternak dikumpulkan dan diambil, kemudian ditimbang untuk mengetahui beratnya dan diambil masing-masing $5 \%$ sebagai sampel. Sampel pakan, sisa pakan dan feses masing-masing ternak selama masa koleksi, dikomposit dan dianalisis komposisi nutriennya secara proksimat (AOAC, 2005). Dari data jumlah pemberian pakan, sisa pakan, jumlah feses serta komposisi nutrien masingmasing, dapat dihitung jumlah konsumsi dan kecernaan bahan kering serta bahan organik.

Proteksi CPO dengan formaldehid. Minyak CPO ditimbang dan dicampur secara merata dengan susu bubuk afkir dengan perbandingan 1:2, kemudian ditambahkan formaldehid teknis $37 \%$ dengan level $0,1,2$, dan $3 \%$ dari berat campuran tersebut, kemudian dicampur kembali secara merata sehingga membentuk CPO yang terkapsulasi (Capsulated Crude Palm Oil - CCPO).

\section{Hasil dan Pembahasan}

\section{Konsumsi bahan kering dan bahan organik}

Hasil penelitian menunjukkan bahwa penambahan CPO (R1) dan CPO yang diproteksi dengan formaldehid (R2) berpengaruh tidak nyata terhadap konsumsi bahan kering dan bahan organik. Dibanding domba yang hanya diberi ransum basal (R0), penambahan CPO (R1) dan CPO yang diproteksi dengan formaldehid (R2) cenderung menurunkan konsumsi bahan kering masingmasing sebesar 122,52 g/ekor/hari dan $81,33 \mathrm{~g} / \mathrm{ekor} / \mathrm{hari}$. Hal yang sama terjadi juga pada konsumsi bahan organik, yaitu penambahan CPO (R1) dan CPO yang diproteksi dengan formaldehid (R2) cenderung menurunkan konsumsi bahan organik masing-masing sebesar 56,79 g/ekor/hari dan 38,18 g/ekor/hari (Gambar 1). Kecenderungan penurunan konsumsi bahan kering dan bahan organik ini disebabkan oleh adanya lemak yang berasal dari CPO yang ditambahkan dalam ransum, yang menyebabkan energi pada ternak telah terpenuhi, sehingga mengurangi konsumsi ransum. Dapat dikatakan bahwa proteksi sumber asam lemak pakan dengan formaldehid memberikan efek yang positif, yaitu lemak pakan dalam ransum terproteksi dengan baik, sehingga walaupun tidak banyak dikonsumsi tetapi dapat memenuhi tingkat kebutuhan ternak. Parakkasi (1999) menyatakan bahwa faktor yang membatasi konsumsi pakan pada ternak adalah kebutuhan energi, yaitu bahwa energi pakan yang terlampau tinggi dapat menurunkan tingkat konsumsi.

\section{Kecernaan bahan kering dan bahan organik}

Hasil penelitian menunjukkan bahwa penambahan CPO (R1) dan CPO yang diproteksi dengan formaldehid (R2) berpengaruh tidak nyata terhadap kecernaan bahan kering dan bahan organik. Dibanding domba yang hanya diberi ransum basal (R0), penambahan CPO (R1) dan CPO yang diproteksi dengan formaldehid (R2) cenderung menurunkan kecernaan bahan kering masing-masing sebesar $0,18 \%$ dan $0,48 \%$. Dibanding domba yang hanya diberi ransum basal (RO), penambahan CPO (R1) dan CPO yang diproteksi dengan formaldehid (R2) cenderung meningkatkan kecernaan bahan organik masing-masing sebesar $1,58 \%$ dan $0,41 \%$ (Gambar 2). Kecernaan bahan kering dan bahan organik dipengaruhi oleh lemak dalam ransum. Dengan penambahan lemak dalam ransum relatif akan menjadi faktor pembatas dalam kecernaan bahan kering, sehingga kecernaan bahan kering pada perlakuan R1 dan R2 sedikit lebih rendah dari R0. Perlu diketahui bahwa proteksi CPO sebagai sumber asam lemak ransum lebih dititikberatkan pada proteksi terhadap sumber asam lemak esensial (linoleat/omega 6 dan linolenat/omega 3) sehingga dapat lolos dan terakumulasi dalam daging Walaupun terjadi kecenderungan penurunan pada parameter konsumsi dan kecernaan, tetapi dampak positif dari proteksi lemak ini adalah peningkatan asam lemak tidak jenuh di dalam daging (Tiven et al., 2013).

\section{Pertambahan bobot badan harian (PBBH)}

Hasil penelitian menunjukkan bahwa penambahan CPO (R1) dan CPO yang diproteksi dengan formaldehid (R2) berpengaruh tidak nyata terhadap $\mathrm{PBBH}$ domba. Dibandingkan domba yang hanya 


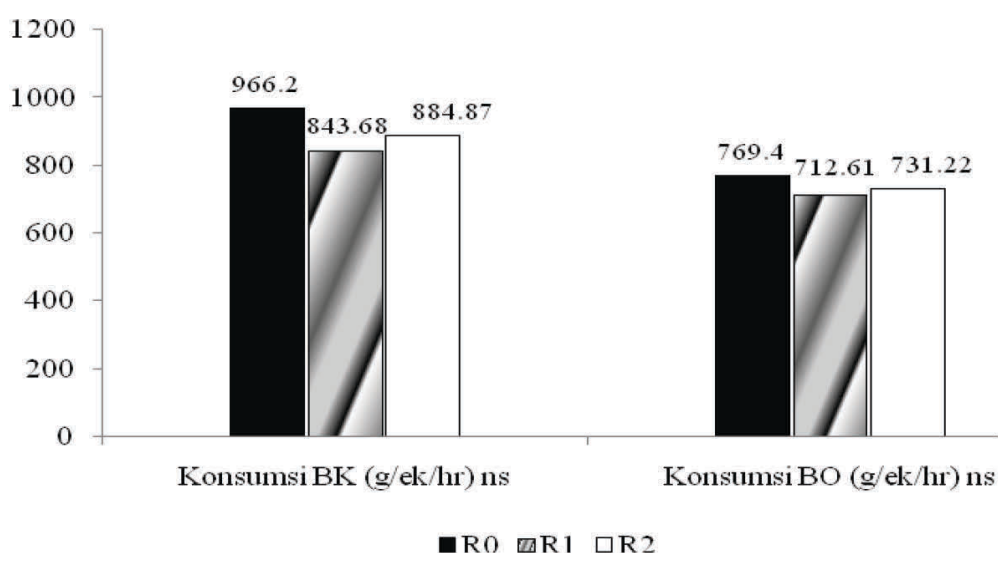

Gambar 1. Pengaruh proteksi CPO dengan formaldehid terhadap konsumsi bahan kering dan konsumsi bahan organik ternak domba ekor tipis (g/ekor/hari). R0: ransum basal, R1: ransum basal dan 3\% CPO, R2: ransum basal dan $3 \%$ CPO yang diproteksi dengan $2 \%$ formaldehid

(the effect of CPO protected with formaldehyde on dry matter and organic matter consumption of thin tail sheep (g/head/day). (R0: the basal ration, $R 1$ : the basal ration and $3 \%$ CPO, R2: the basal ration and $3 \%$ CPO protected with $2 \%$ formaldehyde).

diberi ransum basal (R0), penambahan $\mathrm{CPO}$ (R1) dan CPO yang diproteksi dengan formaldehid (R2) cenderung meningkatkan PBBH $(P=0,29)$, masing-masing sebesar 0,36 g/ekor/hari dan 19,27 g/ekor/hari (Gambar 3). Nilai PBBH pada perlakuan R2 cenderung meningkat dibandingkan perlakuan R0 dan R1. Nilai PBBH ini masih lebih tinggi dari penelitian Rachmadi (2003) pada domba yang diberi pakan yang mengandung bungkil inti sawit (BIS) yang diproteksi dengan $5 \%$ formaldehid memperoleh nilai rataan $\mathrm{PBBH}$ sebesar
44,7 g/ekor/hari tetapi tidak memberikan pengaruh yang nyata. $\mathrm{Di}$ sisi lain kecenderungan peningkatan $\mathrm{PBBH}$ akibat dampak positif proteksi lemak dengan formaldehid (R2) dapat meningkatkan kualitas kimia dan fisik daging. Proteksi lemak dengan formaldehid (R2) dapat meningkatkan kadar lemak tidak jenuh dalam daging $(P<0,05)$, yang membuat daging menjadi lebih empuk $(P<0,01)$, dibandingkan daging domba yang hanya diberi ransum basal (R0) dan ransum dengan penambahan CPO (R1) (Tiven, 2011).

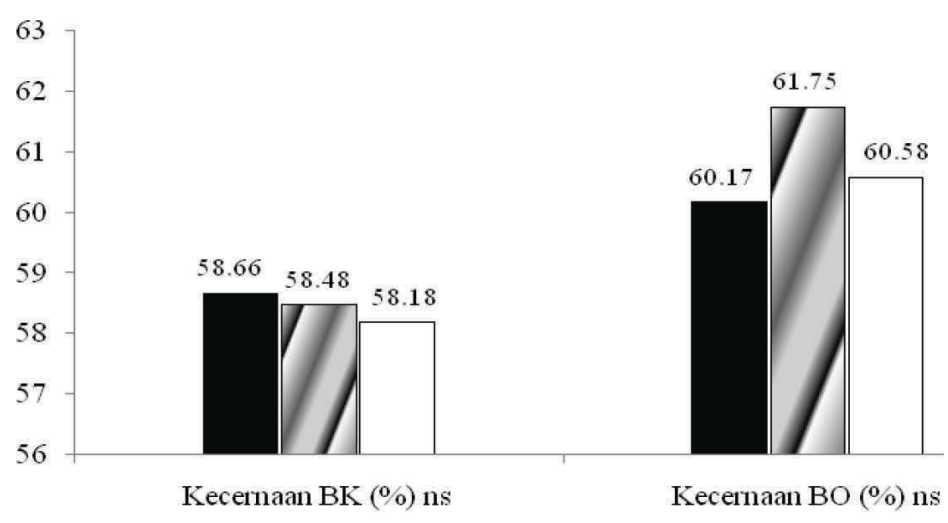

a 0 0 R1 $\square \mathrm{R} 2$

Gambar 2. Pengaruh proteksi CPO dengan formaldehid terhadap kecernaan bahan kering dan kecernaan bahan organik ternak domba ekor tipis (\%). R0: ransum basal, R1: ransum basal dan $3 \%$ CPO, R2: ransum basal dan $3 \%$ CPO yang diproteksi dengan $2 \%$ formaldehid

(the effect of CPO protected with formaldehyde on dry matter and organic matter digestibility of thin tail sheep (\%). (R0: the basal ration, R1: the basal ration and 3\% CPO, R2: the basal ration and 3\% CPO protected with $2 \%$ formaldehyde). 


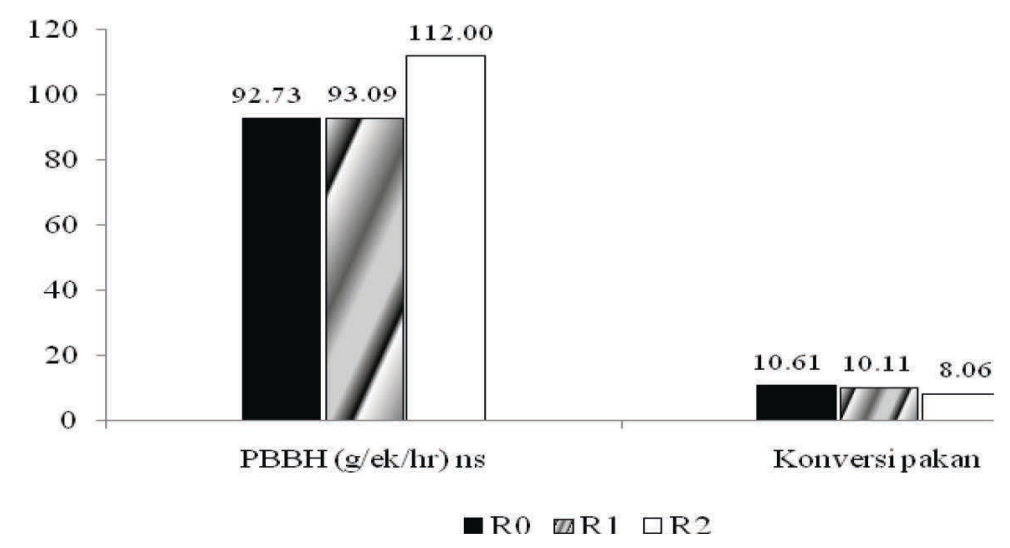

Gambar 3. Pengaruh proteksi CPO dengan formaldehid terhadap pertambahan bobot badan harian (g/ekor/hari) dan konversi pakan ternak domba ekor tipis. R0: ransum basal, R1: ransum basal dan $3 \% \mathrm{CPO}$, R2: ransum basal dan $3 \%$ CPO yang diproteksi dengan $2 \%$ formaldehid

(the effect of CPO protected with formaldehyde on body weight gain ( $\mathrm{g} / \mathrm{head} /$ day) and feed conversion of thin tail sheep). (R0: the basal ration, R1: the basal ration and 3\% CPO, R2: the basal ration and 3\% CPO protected with $2 \%$ formaldehyde).

\section{Konversi pakan}

Hasil penelitian menunjukkan bahwa penambahan CPO yang diproteksi dengan formaldehid (R2) mempunyai angka konversl pakan yang sangat nyata $(P<0,01)$, yaitu lebih rendah dibanding perlakuan R0 dan R1, masing-masing sebesar 2,55 dan 2,05 (Gambar 3). Hal ini menunjukkan efektivitas penggunaan ransum akibat proteksi lemak. Konversi pakan adalah banyaknya pakan yang dibutuhkan untuk meningkatkan satu satuan pertambahan bobot badan (Purbowati, 2007). Nilai konversi pakan pada perlakuan R2 sebesar 8,06 lebih baik dibandingkan perlakuan lainnya sehingga penggunaan ransumnya lebih efisien. Hasil ini relatif lebih baik dari penelitian Rachmadi (2003) yang memproteksi bungkil inti sawit (BIS) menggunakan formaldehid, dengan nilai konversi pakan antara 9,4-14,5.

\section{Kesimpulan}

Penambahan CPO yang diproteksi dengan formaldehid (R2) dalam ransum ternak domba ekor tipis berdampak positif pada penurunan angka konversi.

\section{Ucapan Terima Kasih}

Terima kasih disampaikan kepada PT. Indofood Sukses Makmur, Tbk yang telah mendanai seluruh penelitian ini melalui Program Indofood Riset Nugraha (IRN) tahun 2011.

\section{Daftar Pustaka}

Antoniewicz, A. M., A. M. Van Vuuren, C. J. Van der Koelen and I. Kosmala. 1992. Intestinal digestibility of rumen undegraded protein of formaldehydetreated feedstuffs measured by mobile bag and in vitro technique. Anim. Feed Sci. Tech. 39: 111-124.

AOAC. 2005. Official Methods of Analysis. $11^{\text {th }}$ edn. Association of Official Analytical Chemists. Washington, DC.

Doreau, M. and Y. Chilliard. 1996. Digestion and metabolism of dietary fat in farm animal. In: An International Conference on Fat in the Diet of Animals and Man the National Exhibition Centre. Birmingham, United Kingdom.

Drackley, J. K. 2007. Overview of fat digestion and metabolism in dairy cows. http://www.thecattlesite.com/ articles/793/overview-of-fat-digestionand-metabolism-in-dairy-cows.

Accessed 5 February 2011.

Felton, E. E. D. and M. S. Kerley. 2004. Performance and carcass quality of steers feed different sources of dietary fat. J. Anim. Sci. 82: 725-732.

Harris, W. 2010. Omega-6 and omega-3 fatty acids: Partner in prevention. Curr. Opin. Nutr. Metab. Care. 13: 125-129. 
Hristov, A. N., P. M. Vander, M. Agle, S. Zaman and C. Schneider. 2009. Effect of lauric acid and coconut oil on ruminal fermentation, digestion, ammonia losses from manure, and milk fatty acid composition in lactating cows. J. Dairy Sci. 92: 5561-5582.

Johnson, M. C. 2007. Understanding Rumen Fermentation: I. Effect of High DHA Algal Oil on Microbial Biohydrogenation and II. Monitoring Microbial Shifts in Response to Antibiotics and Oil Using T-RFLP Analysis. Thesis Master of Science Nutrition and Animal Science, Raleigh, North Carolina.

Parakkasi, A. 1999. Ilmu Nutrisi dan Makanan Ternak Ruminan. Universitas Indonesia (UI-Press), Jakarta.

Purbowati, E. 2007. Kajian perlemakan karkas domba lokal dengan pakan komplit dari jerami padi dan konsentrat pada bobot potong yang berbeda. Disertasi Universitas Gadjah Mada, Yogyakarta.

Rachmadi, D. 2003. Dampak pemberian bungkil inti sawit dan konsentrat yang dilindungi formaldehida pada domba terhadap kinerja dan kandungan asam lemak poli tak jenuh. Disertasi. Program Pascasarjana IPB, Bogor.

Sampaio, K. A., R. Ceriani., S. M. Silva., T. Taham and A. J. A. Meirelles. 2011. Steam deacidification of palm oil. Food Bioprod. Process. 89: 383-390.

Scott, T. W., L. J. Cook, K. A. Ferguson, I. W. McDonald, R. A. Buchana and G. Loftus. 1970. Production of polyunsaturated (milk fat in domestic ruminants). Aust. J. Agric. Sci. 32: 291-293.
Sharma, S. K. and B. N. Gupta. 1984. Effect of formaldehyde treatment of groundnut cake on the solubility, in vitro amonia release and degradability of its protein in the rumen. Indian. $\mathrm{J}$. Nutr. Diet. 21: 50-58.

Tiven, N. C. 2011. Kajian minyak sawit kasar yang diproteksi dengan formaldehid sebagai aditif pakan untuk meningkatkan kualitas daging domba. Disertasi Universitas Gadjah Mada, Yogyakarta.

Tiven, N. C., L. M. Yusiati, Rusman and U. Santoso. 2013. Effect of crude palm oil protection with formaldehyde on hydrogenation of rumen fluid unsaturated fatty acid: its effect on blood an meat fatty acid. Indo. J. Chem. 13: 142-148.

Tiven, N. C., L. M. Yusiati, Rusman dan U. Santoso. 2011a. Minimize the hydrogenation of unsaturated fatty acid in rumen with formaldehyde. Indo. J. Chem. 11: 43-47.

Tiven, N. C., L. M. Yusiati, Rusman, dan U. Santoso. 2011b. Ketahanan asam lemak tidak jenuh dalam crude palm oil terproteksi terhadap aktivitas mikrobia rumen domba in vitro. Media Peternakan 34: 42-49.

Vafa, T. S., A. A. Naserian and A. R. H. Moussavi. 2009. Effect of different levels of fish oil and canola oil on in vitro and in vivo nutrient digestibility. Res. Biol. Sci. 4: 1221-1226.

Wartew, G. A. 1983. The health hazards of formaldehyde. J. App. Tox. 3: 121-165.

Willett, W. C. 2007. The role of dietary $n-6$ fatty acids in the prevention of cardiovascular disease. J. Cardiovasc. Med. 8: 42-45. 